\title{
A Study on Vocational College English Teaching Based on Working Process
}

\author{
Lv Xin \\ Foreign Language Department \\ Jilin Business and Technology College \\ Changchun, China \\ 182076127@qq.com
}

\begin{abstract}
At present, there are still many problems in English teaching in higher vocational colleges in China, such as the lack of direction in the textbooks, simple teaching mode, lack of excellent teachers, simple evaluation methods and so on. In view of these problems above, the writer points out that the English teaching based on work process is an effective way to solve the above problems after extensive research. The implementation of English teaching based on work process in vocational colleges should develop curriculum content that is consistent with the development of the work process. We also should build a modularized and three-dimensional curriculum system, train a number of professional English teachers, and adopt the scientific teaching evaluation method. This paper will study the English teaching based on work process in higher vocational colleges, analyzes the problems, and puts forward corresponding countermeasures to cultivate more qualified employees for the society.
\end{abstract}

Keywords-Working Process; Vocational College English; Practice; Combination of Learning with Working

\section{INTRODUCTION}

The higher vocational education is an important part of higher education system and the enrollment of major higher vocational colleges accounts for a very large proportion in higher education. The purpose for developing higher vocational education is to deliver a good deal of service, production and management talents. In higher vocational education, English language teaching is an important subject, playing a crucial part in improving students' comprehensive quality. In the following part, the vocational college English teaching will be introduced so as to promote its development. [1][2]

\section{Main Contents of Vocational College EngLish TEACHING BASED ON WORKING PROCESS}

\section{A. Combination of Course Content with Job Requirement}

When selecting the vocational college English teaching contents, the personal characteristics and the position requirements should be taken into consideration. For the vocational college English teaching, both the theoretical and practical knowledge should be combined with the job demands. During the teaching process, the English competence and knowledge without great demand can be reduced or canceled appropriately and the English knowledge with great demand can be increased appropriately. On this basis, the proper reformation should be conducted for the vocational college English teaching to combine the course contents with future jobs so that the pertinence of vocational college English teaching can be enhanced.

\section{B. Combination of Course Content with Working Process}

During the vocational college English teaching process, the English language teaching contents and working process should be combined organically so that the students can experience the actual work environment; only in such learning atmosphere can the students integrate the theoretical knowledge, practical skills and practical work together. Meanwhile, the students can experience the stringency and convergence of work task during the learning process so that the students' English accomplishment and professional consciousness can be enhanced; in this way, the English knowledge can be transformed into practical application through discovering, analyzing and solving problems.

\section{Combination of Course Content with Work Task}

For the vocational college English teaching, the teaching activities can be determined according to the actual work tasks and the teaching method can integrate the contents with the future work and make the students aware of the significance for combining the learning contents with the practical work so that the classroom learning enthusiasm can be enhanced and the students can concentrate on the daily study with more learning time and vigor. Meanwhile, during such teaching process, the students can realize that the English knowledge should be mastered so as to better complete the tasks. Hence, the vocational college students should combine English study with practical work task so as to realize the value of vocational college English teaching.[3]

\section{DeSign PRINCIPLE OF VocATIONAL COLLEGE ENGLISH TEACHING BASED ON WORKING PROCESS}

\section{A. Principle of Typicality and Applicability}

The traditional vocational college English teaching fails to motivate the students' learning interest because most of the students fail to see the influence of English study on future development and some even think that learning English is valueless. However, the purpose of higher vocational education 
is to cultivate more high-end skilled talents. After learning in higher vocational colleges, the students will devote to the forefront of production and the employment posts are grassroots work. Hence, the vocational college English teaching based on job demand should pay attention to the design of teaching content and carry out the courses based on the position requirements. For the science and engineering students, the English language teaching should be arranged around engineering surveying, equipment using, maintenance and construction.[4] For the management students, the English language teaching should be designed around document processing and interpersonal communication. The English learned in the college should be combined with the specialized courses so that the students can be fully aware of the relevance between English knowledge and future job. Meanwhile, for the design of vocational college English teaching, the typicality principle and applicability principle should be obeyed; only in this way can the students realize the function of vocational college English teaching.

\section{B. Student-centered Principle}

Compared with the students in universities, the students in higher vocational colleges are lack of the necessary learning motivation and initiative; therefore, the teachers should regard the students as the center during the teaching process to make the reasonable arrangement on the classroom teaching contents so that the learning interest can be brought in the classroom. Compared with the teaching of other subjects, the English learning process is relatively boring and thus the teachers should take account of the applicability of English language teaching and bring in the future job content during the teaching design process so as to enhance the enjoyment of classroom teaching and improve the English learning enthusiasm. Simultaneously, the vocational college English teachers should lay emphasis on role transition and establish the studentcentered concept. The traditional teaching mode of teacher lecturing and student learning should be abandoned and the inflexible and boring teaching method should be improved so that the students can be the active participants in English language teaching. [5]Through the English language teaching in various forms, the students can experience the learning process of English language teaching based on working process and learn in the novel, relaxed and actual working environment. As thus, the vocational college students will change from passive to active and spend more time on learning and exploring.

\section{Existing Problems of Vocational College English TEACHING IN CHINA}

\section{A. Deficient Feature and Pertinence in Textbook Content}

At present, most of English textbooks in higher vocational colleges are lack of characteristic and pertinence and are separated from social need, thus leading to the low matching rate between English language teaching contents and future work. As thus, the students' learning interest can't be motivated and the classroom teaching effect is classroom teaching effect, which is disadvantageous for the students to promote English application ability in the future work.

\section{B. Undefined English Teaching Objectives}

In 2000, the Ministry of Education issued Basic Requirements on English Course Teaching in Higher Vocational Technical Education, in which the major teaching objective of vocational college English teaching was put forward, which required that the students should have a comprehensive mastery of basic English knowledge with certain listening, speaking, reading and writing abilities and should be able to translate materials involved in the related work with the help of dictionary as well as do the daily oral communication during the foreign communication through the 180 to 220 hours of English language teaching. However, in actual English language teaching, the vocational college English teachers fail to conduct the classroom teaching according to the above requirements; compared with the English language teaching in undergraduate colleges, the English teaching contents in vocational colleges are relatively easy with focus on classroom teaching contents; however, insufficient attention is paid to listening, speaking and writing and thus the classroom teaching effect is unsatisfactory. [6]

\section{Single Teaching Model and Low Student Learning Interest}

At present, most of the vocational college English teaching remains in traditional teaching method that is the teaching model of teacher lecturing and students listen without paying attention to the principal status of students. For such teaching model, the students can only accept the course contents passed on by the teachers and some may even lose interest in vocational college English teaching owing to the poor English foundation.

\section{Single Teaching Evaluation Methodology, Unfavorable for Student Development}

At present, for the English language teaching in higher vocational colleges, the teachers apply the single evaluation method for the students' school records, that is the written test and the test score has become the essential foundation for measuring the students' learning results. Such evaluation system only lays emphasis on the examination of students' reading and writing abilities and thus fails to inspect the students' English application abilities as well as provide references for the teachers' improvement on teaching methods, which is disadvantage for the student development.

\section{MEASURES FOR IMPROVING VOCATIONAL COLLEGE ENGLISH TEACHING QUALITY}

\section{A. Improving Teachers' Comprehensive Qualities}

Although the teaching ideas in higher vocational colleges have been improved and the student-oriented teaching model initiated, the role teachers play in the vocational college English teaching is still fundamental. In particular, the vocational college English teaching based on working process brings in a good deal of professional English knowledge, considers the practical work as the subject and requires the teachers to have a comprehensive understanding of professional knowledge, which is the condition most vocational college English teachers fail to have. Firstly, the teachers should change the intentions inwardly. In the past learning 
process, the vocational college English teachers experienced the traditional English language teaching; therefore, they should reform the existing teaching contents and promote the comprehensive quality so as to keep up with the times. If the teachers fail to reform inwardly, then teaching process can't be realized successfully. Secondly, the teachers should be familiar with the job contents and working processes of the relevant posts so as to better adopt the vocational college English teaching based on working process; if the teachers fail to have a understanding of the working process, the vocational college English teaching based on working process will make no sense. Consequently, if is of great significance to improve the teachers' comprehensive ability.

\section{B. Optimizing English Language Teaching Process}

For the vocational college English teaching based on working process, the teaching process generally includes lesson preparation, classroom teaching and teaching summary. During the lesson preparation of English language teaching, the teachers should formulate the learning tasks and teaching programs according to the teaching objectives and student characteristics and print the assignment books, attendance sheet and evaluation forms. Classroom teaching is the subject of teaching implementation and in this stage; the teachers should guide the students to have a comprehensive understanding of teaching objectives, teaching contents and evaluation modes so as to ensure that the students can finish the corresponding learning tasks smoothly. During the teaching summary stage, the teachers should analyze and summarize the teaching contents and teaching results so as to provide references for the next stage. During this process, the vocational college English teachers should assess the teaching results and put forward the targeted recommendations for improvement. Meanwhile, the teachers should urge the students to collate the teaching materials involved in the classroom teaching so as to enhance the English language teaching quality. [7]

\section{Developing On-the-spot teaching with the Help of Training Bases in and around School}

For the vocational college English teaching based on working process, the on-the-spot teaching in the training bases in and around the schools should be developed according to the requirements of vocational posts and work flows. The higher vocational schools should bring the teaching from classrooms to the training bases to carry out the teaching model of "unity in production and practical training, unity in learning and doing and unity in teaching and technical service", which can transform the abstract professional theories into specific practices. In this case, the students can feel the actual work environment so that the English learning interest can be motivated and the English communicative competence can be enhanced and trained.

\section{Exploiting English Language Teaching Contents Conforming to Working Process}

Firstly, when designing the vocational college English teaching contents, the working process should be investigated; for example, for the students majoring in mechanical \& electrical integration, the teachers should investigate the following contents: (1) the first-line operators of electrical and mechanical manufacturing enterprises; (2) the assembly technicians of mechanical and electrical scenes; (3) maintenance and management personnel of mechanical and electrical equipment; (4) sales and after sales service personnel of mechanical and electrical equipment. When studying the students' adaption to posts in virtue of English, the teaching contents of electrical and mechanical English courses should be set according to the relevant technical requirements in order to improve the skills and knowledge points the students should master. On this basis, the electrical and mechanical English textbooks confirming to position English should be compiled when designing the course contents of vocational college English. Secondly, under the guidance of the above idea, the vocational college English teachers can develop the electrical and mechanical English courses during the teaching process with the concrete contents of electrical and mechanical production process, job seeking processes of graduates of mechanical and electrical specialty and electrical and mechanical sales process. Only in this way can "learning in classroom" and "learning during working process" be combined and the professional qualification analysis (including work analysis, job analysis and enterprise production process analysis), occupational planning and vocational college English curriculum design be combined effectively. What the curriculum design of vocational college English teaching based on working process needs has changed from the systematization of subject frame to the systematization of working process that emphasizes the pertinence and practicability of English knowledge.

\section{E. Constructing Scientific English Language Teaching Evaluation System}

For the vocational college English teaching based on working process, the traditional evaluation method is applied, however, the evaluation effect is unfavorable and thus it should be reanalyzed and constructed. Nowadays, the project process evaluation method is introduced to the vocational college English teaching based on working process and it generally assesses the typical work task to realize the evaluation on school record. This evaluation system includes production demonstration, evaluation on project paper, mutual evaluation among group members and teacher evaluation. For each learning team, students should demonstrate after finishing the ordered mission. During the demonstration process, the students should conduct self-assessment on the work program they have participated in and then the teachers should conduct the summative evaluation and the enterprise can check the quality of the final project report when necessary. In this way, the vocational college students can learn how to evaluate others and themselves objectively and draw on the strong points of others to make up for their own weak points so as to lay good foundation for the development of follow-up project.

\section{CONCLUSIONS}

Nowadays, the higher vocational education system is reformed and deepened continuously; however, there are still defects and deficiencies, hindering the development of vocational college English teaching. Hence, the relevant 
teachers should launch vocational college English teaching based on working process and formulate the targeted systematic classroom English teaching according to students' characteristics and future work so as to enhance the English learning interests and results of students and lay good foundation for their future work.

\section{REFERENCES}

[1] Dou Juhua. An Empirical Study on Project-oriented Teaching Model of Higher Vocational Public English Based on Working Process. [J]. Journal of Hunan University of Science and Engineering, 2012, 6(12):57-58.

[2] Yuan Jingli. A Study on Travel English Teaching Reform Based on Working Process - Taking Yichun Vocational College as Example [J].
Liaoning Economic Vocational Technological Institute · Journal of Liaoning Economic Management Cadre Institute, 2013, 6(5):175-176.

[3] Du Lihong. The Study and Practice of Vocational College English Teaching Based on Working Process [J]. Education Exploration, 2013, 4(12):111-112.

[4] Shi Zhongying. Knowledge Transformation and Education Reform[M]. Beijing. Education Science Press.2005:35-38

[5] Yuan Jiang. Courses Conception Based on Working Process[J]China Vocational Technology Education.2005(04).

[6] Li Mingzhu, Yuan Qinying. On Higher Vocational English Teaching Mode[J]New Curriculum Research. 2013(04).

[7] Zhou Yi. Application on Multimoddal Teaching mode in English Teaching in Higher Vocational Colleges[J]. Vocational and Technical Education Forum.. 2013(17). 